University of Rhode Island

DigitalCommons@URI

The Rhode Island Current Conditions Index

Economics

$5-2007$

\title{
Rhode Island Current Conditions Index - May 2007
}

Leonard Lardaro

University of Rhode Island, lardaro@uri.edu

Follow this and additional works at: https://digitalcommons.uri.edu/ricci

Part of the Econometrics Commons

Terms of Use

All rights reserved under copyright.

\section{Recommended Citation}

Lardaro, Leonard, "Rhode Island Current Conditions Index - May 2007" (2007). The Rhode Island Current Conditions Index. Paper 66.

https://digitalcommons.uri.edu/ricci/66

This Article is brought to you for free and open access by the Economics at DigitalCommons@URI. It has been accepted for inclusion in The Rhode Island Current Conditions Index by an authorized administrator of DigitalCommons@URI.For more information, please contact digitalcommons-group@uri.edu. 


\section{GURRENT}
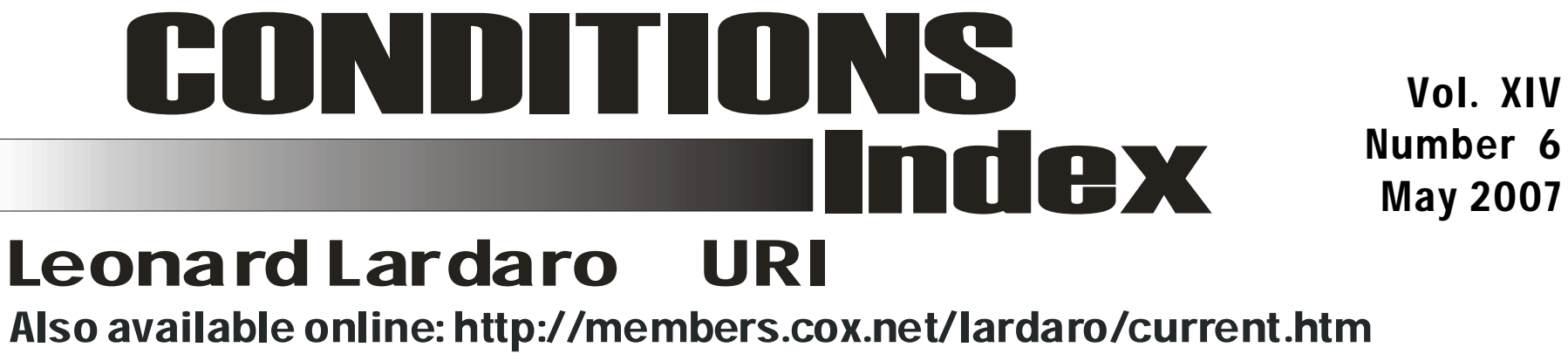

As we move toward the end of the second quarter, there is good news for Rhode Island: the Current Conditions Index emerged from its two month slump (with a neutral and a declining value) all the way back to 67 , its highest level since last December. Eight of the twelve $\mathrm{CCl}$ indicators improved in May. And unlike April, there was very little in terms of mitigating circumstances behind these indicator performances.

Five indicators turned in very strong performances in May. Retail Sales grew sharply above its value last May, as did US Consumer Confidence, Employment Service Jobs, and Single-Unit Permits. The Unemployment Rate was significantly lower than its level last May, accompanied by a rising Labor Force. Only two of these, Employment Service Jobs and Single-Unit Permits had qualifications. For Employment Service Jobs, its May growth of 3.0 percent was very good historically, but well below both April's rate and

\begin{tabular}{lr}
\multicolumn{2}{c}{ CCI Indicators - \% Change } \\
Government Employment & -0.2 \\
US Consumer Sentiment & $12.0 \mathbf{Y}$ \\
Single-Unit Permits & $9.6 \mathbf{Y}$ \\
Retail Sales & $6.3 \mathbf{Y}$ \\
Employment Services J obs & $3.0 \mathbf{Y}$ \\
Priv. Serv-Prod Employment & $1.9 \mathrm{Y}$ \\
Total Manufacturing Hours & -2.9 \\
Manufacturing Wage & $2.5 \mathbf{Y}$ \\
Labor Force & $0.2 \mathrm{Y}$ \\
Benefit Exhaustions & 9.3 \\
New Claims & 3.9 \\
Unemployment Rate & $-7.7 \mathbf{Y}$ \\
\multicolumn{1}{|c}{ Y = I mproved Value } &
\end{tabular}

the string of double-digit growth rates we saw from October through March. As this is a leading economic indicator, its May performance may be pointing to sluggish job growth ahead. Single-Unit Permits grew by 9.6 percent compared to last May, but its value last May was extremely low, making May's growth more of a move off of an extremely weak "comp." Clearly, the recent behavior of this indicator has been extremely volatile, making its overall trend difficult to discern.

Now for the really good news. Retail Sales turned in a very strong performance in May, growing by 6.3 percent, rising to its highest level since December. Along with this, US Consumer Confidence moved out of its recent doldrums, increasing by a very healthy 12 percent in May, its first improvement in three months.
Rhode Island's Unemployment Rate dropped from 5.2 percent last May to 4.8 percent this May. And, in terms of what matters a great deal in gauging any improvement in this indicator for Rhode Island, this was accompanied by a rising Labor Force. For May, Rhode Island's resident Labor Force rose by 0.2 percent compared to a year ago. One precautionary note, however, is that Labor Force growth continues to less than it was since October of last year.

Looking at the other labor market indicators, Private Service Producing Employment grew by 1.9 percent in May, a noticeable improvement over April, and more consistent with what had been a trend of about 2 percent growth. Rhode Island's manufacturing sector turned in a mixed performance. Total Manufacturing Hours fell by 2.9 percent, its worst performance since last September. As this occurred, Manufacturing Wage growth accelerated sharply to 2.5 percent in May, its strongest growth since last June. Government Employment fell once again, by 0.2 percent in May, its eighth consecutive decline. And finally, the performance of a critical labor market pair deteriorated in May. New Claims for Unemployment Insurance, which measures layoffs, rose by 3.9 percent, while at the other end of the layoff spectrum, Benefit Exhaustions, which reflects longterm unemployment, rose by 9.3 percent.

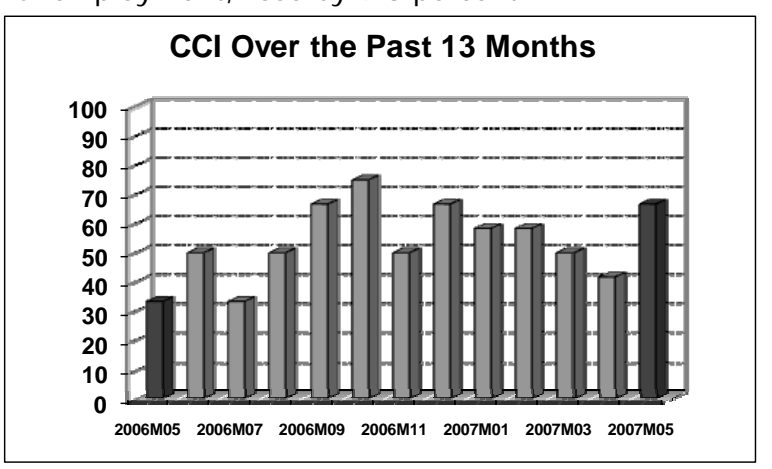

\section{THE BOTTOM LINE}

What a difference a month makes! Rhode Island moved out of a "soft patch" with significant improvement in May. Acceleration at this juncture is critical, as our sizeable budget deficits will soon begin to slow our rate of economic growth, not only hurting tax revenue growth, but causing our deficit to get worse before it gets better.

\begin{tabular}{|c|c|c|c|c|c|c|c|c|c|c|c|c|}
\hline & Jan & Feb & Mar & Apr & May & J un & $\mathbf{J} \mathbf{~ u}$ & Aug & sep & Ōct & Nov & Dec \\
\hline 2006 & 58 & 58 & 58 & 42 & 33 & 50 & 33 & 50 & 67 & 75 & 50 & 67 \\
\hline 2007 & 58 & 58 & 50 & 42 & 67 & & & & & & & \\
\hline
\end{tabular}

